GRASAS Y ACEITES 71 (2)

April-June 2020, e358

ISSN-L: 0017-3495

https://doi.org/10.3989/gya.0344191

\title{
Role of lactic acid bacteria in fermented vegetables
}

\author{
J. Bautista-Gallego ${ }^{\mathrm{a}}$, E. Medina ${ }^{\mathrm{a}, \boldsymbol{}}$, B. Sánchez ${ }^{\mathrm{b}}$, A. Benítez-Cabello a and F.N. Arroyo- López \\ ${ }^{a}$ Food Biotechnology Department. Instituto de la Grasa (CSIC). University Campus Pablo de Olavide, \\ Building 46. Ctra. Utrera, km 1. 41013 Seville (Spain). \\ ${ }^{\mathrm{b}}$ MicroHealth Group. IPLA (CSIC). Paseo Rio Linares s/n. 33300 Villaviciosa, Asturias (Spain). \\ Corresponding author: emedina@ig.csic.es
}

Submitted: 22 March 2019; Accepted: 06 June 2019; Published online: 26 May 2020

SUMMARY: The consumption of fermented vegetables is widespread throughout the world and represents an important component of the human diet with considerable contribution to the food supply for a world population in continuous growth. Many of the fermented vegetables share a general process which requires salting and acidification steps. Among the microorganisms responsible for fermentation, lactic acid bacteria are the most relevant with important organoleptic, quality and safety benefits. This review deals with the microbial ecology of fermented vegetables focusing on the biodiversity of lactic acid bacteria, the most important molecular techniques used for their identification and genotyping, their importance for the formation of biofilms as well as their use as starter cultures for obtaining high-quality and safe vegetable products.

KEYWORDS: Biofilms; LAB biodiversity; Multifunctional starters; Vegetables

RESUMEN: Papel de las bacterias del ácido láctico en verduras fermentadas. El consumo de vegetales fermentados está muy extendido en el mundo y representa un componente importante de la dieta humana con un apoyo considerable a la cadena alimentaria para una población mundial en continuo crecimiento. Muchos de los vegetales fermentados comparten un proceso general, que requiere una puesta en salmuera y acidificación. Entre los microorganismos responsables de la fermentación, las bacterias del ácido láctico son las más relevantes con una importante influencia sobre aspectos organolépticos, de calidad y seguridad del producto final. Esta revisión trata sobre la ecología microbiana de los vegetales fermentados, prestando especial atención a la biodiversidad de las bacterias del ácido láctico, las técnicas moleculares más importantes utilizadas para su identificación y genotipado, su importancia para la formación de biofilms y su uso como cultivos iniciadores multifuncionales para la obtención de productos vegetales de alta calidad y seguridad.

PALABRAS CLAVE: Biodiversidad de BAL; Biofilms; Cultivos iniciadores multifuncionales; Vegetales

ORCID ID: Bautista-Gallego J https://orcid.org/0000-0003-0654-8029, Medina E https://orcid.org/0000-0002-99784524, Sánchez B https://orcid.org/0000-0003-1408-8018, Benítez-Cabello A https://orcid.org/0000-0001-9978-1617, Arroyo-López FN https://orcid.org/0000-0001-6308-7746

Citation/Cómo citar este artículo: Bautista-Gallego J, Medina E, Sánchez B, Benítez-Cabello A, Arroyo-López FN. 2020. Role of lactic acid bacteria in fermented vegetables. Grasas Aceites 71 (2), e358. https://doi.org/10.3989/ gya.0344191

Copyright: ( 2020 CSIC. This is an open-access article distributed under the terms of the Creative Commons Attribution 4.0 International (CC BY 4.0) License. 


\section{INTRODUCTION}

Fermented vegetables (cucumber, kimchi, sauerkraut, capers, carrots, table olives, etc.) play an important role in the human diet as a source of water-soluble vitamins, dietary fiber, phytosterols, phytochemicals and minerals (Gebbers, 2007). They also represent fundamental support for the feeding of a growing population. Fermentation is considered one of the oldest and cheapest methods used in food technology for food preservation. In addition, fermentation confers favorable effects to vegetables by improving the organoleptic characteristics of the final product (taste, color, texture, etc.), eliminates anti-nutritional components, prolongs shelf-life and increases the safety of the final products. The first reference of fermented vegetables was found in China during the construction of the Great Wall in III B.C. and constituted the basis of the workers' diet (Andersson, Daeschel and Eriksson, 1988).

Fermented vegetables can be considered both the edible part of the fruits (seeds and pulp) and other parts of the plant (leaves and roots). Many fermented vegetables share a common elaboration process which requires the use of salt and acidification by microorganisms (Figure 1). Sometimes a pre-step such as $\mathrm{NaOH}$ treatment, water washing, scalding, etc. is required, after harvesting the fruit. Pickles are prepared under three basic types of conditions: dry-salted, immersed in brine or non-salted cover solutions, where the fermentation takes places during storage (Montet et al., 2014). The development of certain autochthonous microorganisms present in the raw material, mainly lactic acid bacteria (LAB) and yeasts, are favored by the manufacturing of fermented vegetables (Di Cagno et al., 2013; Arroyo-López, et al., 2012b). The process of lactic fermentation consists of the conversion of sugars, mainly glucose, into lactic acid, which produces acidification at $\mathrm{pH}$ values below 4.6 units. This acidification inhibits the growth of undesirable spoilage and pathogenic microorganisms that can generate risks for public health.

\section{THE MICROBIAL ECOLOGY OF FERMENTED VEGETABLES}

The microorganisms present during vegetable fermentation are very diverse and may considerably affect the quality and safety of the final product. The microbiota initially present in the processes of lactic fermentation comes mainly from the fruit, although other elements such as brines, ingredients used and the industry's own environment influence its composition. The microbiota that colonizes the surface, and even the interior of the fresh fruit, is varied and depends on factors such as fruit maturity, climate and agricultural practices (Samish et al., 1963; Mattos et al., 2005). Mesophilic aerobic microorganisms on the surface of fresh pickles and cabbage can reach population levels of up to $5 \log _{10}$ CFU/mL (Pérez-Díaz et al., 2015). This microbial

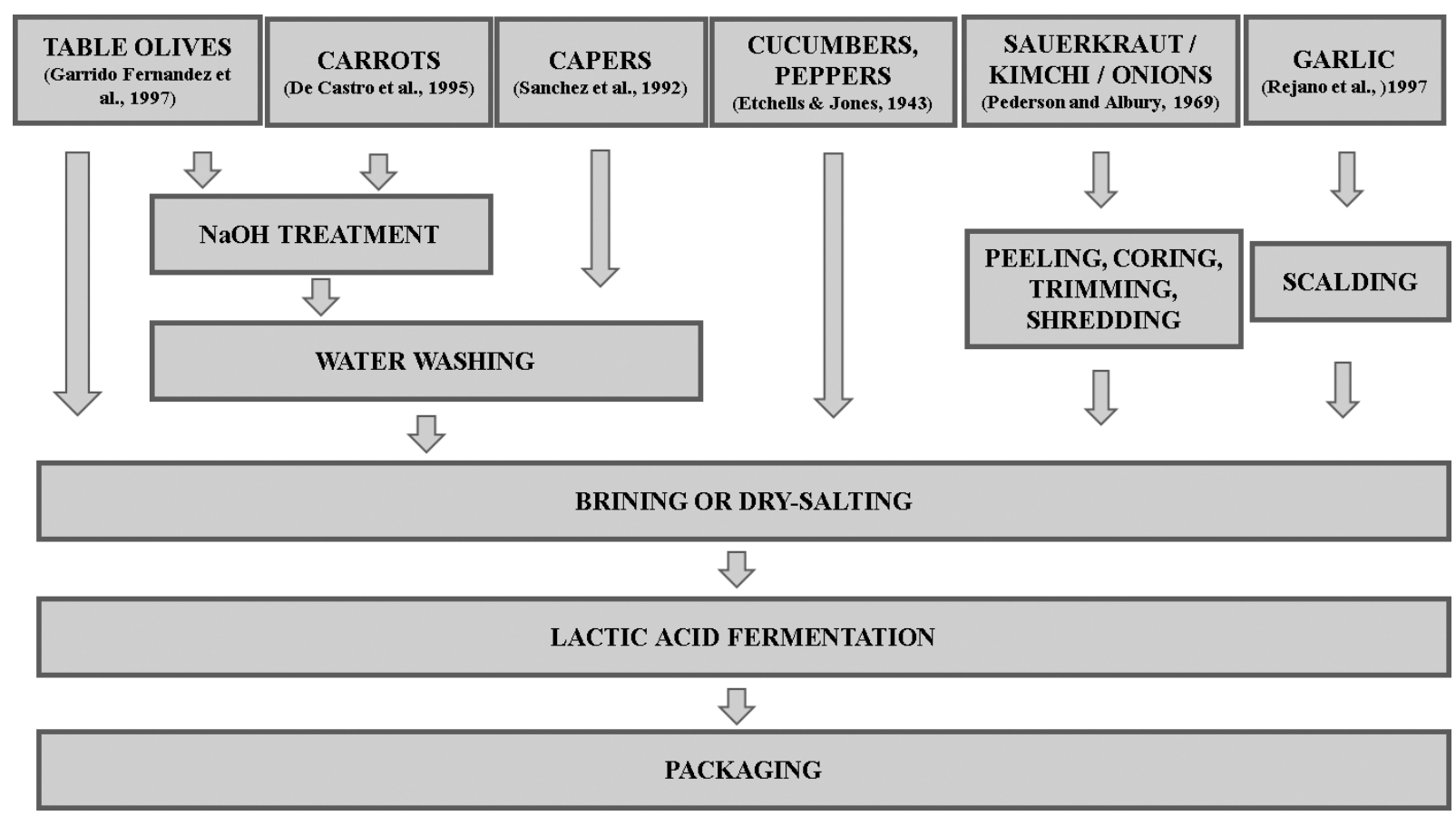

Figure 1. Flowchart of diverse fermented vegetable elaboration processes. 
diversity is drastically reduced as the fermentation process evolves due to changes in the chemical conditions, mainly $\mathrm{pH}$, acidity and salt concentration. A selection is made between the best adapted microbial groups and among them they compete for the nutrients and the dominance of the process. Enterobacteria, LAB and other groups of bacteria and yeasts can be active during the early stages of fermentation, depending on factors such as temperature, dissolved oxygen and the concentration of salts used in the brines. Subsequently, there is dominance by LAB (mainly Lactobacillus, Pediococcus, Enterococcus and Leuconostoc genera) throughout fermentation.

LAB are characterized by transforming fermentable material, mainly glucose and fructose, into organic acids through fermentation. The initial steps of vegetable fermentations are usually carried out by heterofermentative microorganisms with the production of lactic and acetic acids which make an important contribution to the flavor and aroma of the final product (Breidt et al., $2013 \mathrm{~b})$. Then, they are replaced by the more acidtolerant homofermentative microorganisms due to their capacity to produce lactic acid which induces a greater decrease in the $\mathrm{pH}$ but that inhibits the development of other microbial groups (Montet et al., 2014). These $\mathrm{pH}$ changes, together with the concentration of salt, are responsible for obtaining stable and safe fermented vegetables. Lactic acid has advantageous preservative properties, which are responsible for fermented products having a longer shelf-life than their non-fermented counterparts. Also, other metabolites generated by LAB such as esters or bacteriocins contribute to the improvement of the organoleptic properties (acid and sour flavor) of the vegetable products produced by these processes. Fermentations carried out by LAB have also permitted the production of a large variety of foods with different aromas, flavors, and consistencies (Lücke, 1996).

In addition to the presence of LAB, yeast populations can also coexist during vegetable fermentation. In fact, they predominate in certain types of elaborations, such as directly brined olives (natural green and black) where the Candida, Pichia, Debaryomyces, and Saccharomyces genera are the most representative (Arroyo-López et al., 2008; Botta and Cocolin, 2012). In the fermentation of gherkins, the genera Torulopsis, Brettanomyces, Zygosaccharomyces, Hansenula, Torulaspora, and Kloeckera also stand out (Etchells and Bell, 1950). Yeasts modulate the final organoleptic profile of the fermented product due to their capacity to produce volatile compounds associated with the development of flavor and aroma (Arroyo-López, et al., 2012b; Hernández et al., 2007; Rodríguez-Gómez et al., 2010). However, yeasts can also be responsible for certain types of alterations. Excessive growth of fermentative yeasts (Saccharomyces cerevisiae and Wicherhanomyces anomalus) could trigger an active production of $\mathrm{CO}_{2}$, which damage the fruits with the formation of gas pockets or produce wiring in table olives (Vaughn et al., 1972; Garrido-Fernández et al., 1997). Certain yeasts, such as Pichia manshurica and Issatchenkia occidentalis, are associated with alterations in fermented vegetables due to their capacity to consume lactic acid and increase the $\mathrm{pH}$ of the product (Franco et al., 2012). Pichia kudriavzevii is considered the main yeast responsible for the production of bad odor and flavor in kimchi, as well as softening (Moon et al., 2014). Other fungi with pectinolytic capacity such as the genera Alternaria, Fusarium and Mucor, are responsible for the softening of pickles in brine (Costilow et al., 1980)

In addition to LAB and yeasts, which are typically found in vegetable fermentations, gram-negative bacteria of the genera Enterobacter, Citrobacter and Escherichia are generally present at the beginning of fermentation. These microbial communities are inhibited because of lactic acid production by LAB, with a concomitant decrease in $\mathrm{pH}$ (GarridoFernández et al., 1997). If the decrease in $\mathrm{pH}$ is not fast, Gram-negative bacteria can grow and produce $\mathrm{CO}_{2}$ and compromise the quality and safety of the product leading to defects associated with the fruit, forming gas-pockets on the surface or inside the fruit, ("alambrado") in gherkins and table olives (Fleming et al., 1975; Garrido-Fernández et al., 1997).

The presence of nutrients and a neutral or alkaline $\mathrm{pH}$ during the first stage of vegetable fermentation can contribute to the growth of Clostridium spp. These spoilage microorganisms can generate odors of decomposing organic matter or rancid butter, symptoms of putrid and butyric fermentations (Gililland and Vaughn, 1943). They are anaerobic spore-forming bacteria capable of colonizing the bottom of the fermenters where the concentration of oxygen is null. Sometimes, undesired secondary fermentation can be initiated by propionic acid bacteria such as Propionibacterium spp., converting sugars or lactic acid into propionic acid and $\mathrm{CO}_{2}$, thus increasing the $\mathrm{pH}$ values (González-Cancho et al., 1980). These conditions also enhance the growth of Clostridium species which, together with Propionibacterium, can promote the so-called "zapatería" alteration, giving off abnormal odors in table olives (Kawatomari and Vaughn, 1956; Plastourgos and Vaughn, 1957) or desirable aromas in sauerkraut (Babuchowski et al., 1999). The resulting $\mathrm{pH}$ rise allows the growth of other microbes which are spoilage or pathogenic, compromising the safety of the product (Medina-Pradas and Arroyo-López, 2015). The presence of acetic acid bacteria and some strains of Lactobacillus spp. plays an important role in the onset of spoilage in fermented cucumbers by converting lactic acid into acetic acid (Johanningsmeier 
and McFeeters, 2013; Medina et al., 2016a). The increase in $\mathrm{pH}$ favors the growth of other species of Propionibacterium and Pectinatus. Clostridium bifermentans and Enterobacter cloacae which can metabolize the lactic acid and generate butyric and propionic acids, respectively (Breidt et al., 2013a; Franco and Pérez-Díaz, 2013), and are responsible for the aroma of cheese and manure characteristic in spoilt fermented pickles.

\section{BIODIVERSITY OF LAB IN FERMENTED VEGETABLES}

The diversity of LAB species present in the different fermented vegetables that can be found on the market is wide, and responds to the different compositions presented by raw material, the environment and the physicochemical conditions prevailing during the fermentation process (Hurtado et al., 2012).

In the specific case of table olives, the most representative genus, as mentioned above, is Lactobacillus, with $L$. pentosus and L. plantarum as the predominant species (Benítez-Cabello et al., 2019; Botta and Cocolin, 2012), which show a great intra-specific diversity with the presence of different biotypes, depending on variety, type of processing, and geographical area. Other microorganisms identified during the fermentation process belong to the genera Enterococcus, Pediococcus, Leuconostoc, and Lactococcus, but always in a smaller proportion. Kimchi is also a fermented vegetable made with cabbages, radish, and various vegetables, and has great production and tradition in South Korea. As in the case of olives, there is also a great diversity of lactic bacteria, especially the genera Weissella, Leuconostoc, and Pediococcus. Furthermore, several species of Lactobacillus and Leuconostoc have been identified in the fermentation of sauerkraut (cabbage). Finally, P. ethanolidurans, E. thailandicus, and different species of the genus Lactobacillus and Leuconostoc have been described as the most abundant species during the production of pickled cucumbers.

As a summary, Table 1 shows the main LAB species identified in diverse types of fermented vegetables.

\section{IDENTIFICATION AND GENOTYPING OF LAB IN FERMENTED VEGETABLES: FROM MORPHOLOGICAL TECHNIQUES TO OMICS APPROACH}

The conventional methods for the identification of LAB are based on morphological and physiological characteristics such as Gram stain, spore formation, enzyme production, and the determination of diverse biochemical reactions. Taking into account these techniques, the API system (BioMerieux, France) has been widely used. This biochemical methodology is based on the fermentative profile presented by microorganisms for a battery of carbohydrates. However, LAB present similar nutritional and growth needs, so these tests are not conclusive in most cases (Randazzo et al., 2004).

At the end of the 90s, different molecular techniques were established, allowing for a more indepth study of the bacterial ecology of food. The partial amplification by PCR (Polymerase Chain Reaction) of the DNA or RNA extracted directly from the microorganisms of interest, and its subsequent sequencing allows for microbial identification with much better precision thanks to the databases,

TABLE 1. Summary of LAB species identified in the main types of fermented vegetables

\begin{tabular}{|c|c|c|}
\hline Vegetable Matrix & Specie & Reference \\
\hline Table olives & $\begin{array}{l}\text { L. pentosus, L. plantarum, L. paraplantarum, } \\
\text { L. parafarraginis, L. sanfranciscensis, Pediococcus sp., } \\
\text { Lc. mesenteroides }\end{array}$ & $\begin{array}{l}\text { (Abriouel et al., 2011; Hurtado et al., 2012; } \\
\text { Bautista-Gallego et al., 2013; Benítez-Cabello et al., } \\
\text { 2016, 2019) }\end{array}$ \\
\hline Kimchi & $\begin{array}{l}\text { L. curvatus, } L . \text { sakei, Lc. mesenteroides, } L c . \text { gelidum, } \\
\text { Lc. carnosum, Lc. gasicomitatum, P. pentosaceus, } \\
W . \text { soli, W. cibaria, W. koreensis, } W \text {. cibaria }\end{array}$ & $\begin{array}{l}\text { (Jung et al., 2013; Jang et al., 2014; Hong et al., } \\
\text { 2015; Ji, Jang and Kim, 2015; Kyung et al., 2015; } \\
\text { Kim } \text { et al., 2017) }\end{array}$ \\
\hline Sauerkraut & $\begin{array}{l}\text { L. plantarum, L. pentosus, } L c . \text { mesenteroides, } \\
\text { L. brevis, L. sakei, L. curvatus, L. paraplantarum, } \\
\text { L. coryniformis, P. pentosaceus, Lc. citreum, } \\
\text { Lc. argentinum, Weissella sp. }\end{array}$ & $\begin{array}{l}\text { (Johanningsmeier et al., 2007; Plengvidhya et al., } \\
\text { 2007; Qing Yue et al., 2013; Yan et al., 2015) }\end{array}$ \\
\hline Cucumbers & $\begin{array}{l}\text { L. pentosus, L. plantarum, L. brevis, L. paracasei; } \\
\text { Weissella spp., P. ethanolidurans, Leuconostoc spp., } \\
\text { Lactococcus spp }\end{array}$ & $\begin{array}{l}\text { (Breidt et al., 2013a; Medina et al., 2016a; Pérez- } \\
\text { Díaz et al., 2016) }\end{array}$ \\
\hline $\begin{array}{l}\text { Other fermented } \\
\text { vegetables }\end{array}$ & $\begin{array}{l}\text { Enterococcus thailandicus E. casseliflavus, Lc. lactis, } \\
\text { Lc. mesenteroides, W. hellenica. L. pentosus, } \\
\text { L. plantarum, L. paraplantarum, L. brevis, } \\
\text { L. citrtreum, L. alimentarius, L. paracasei, } \\
\text { L. buchneri, P. ethanolidurans }\end{array}$ & $\begin{array}{l}\text { (Breidt et al., 2013b; Tamminen et al., 2004; Chen } \\
\text { et al., 2012; Yu et al., 2012; Wouters et al., 2013; } \\
\text { Elmac1 et al., 2015; Reina } \text { et al., 2015) }\end{array}$ \\
\hline
\end{tabular}


such as NCBI GenBank (https://blast.ncbi.nlm. nih.gov/Blast.cgi). Other molecular techniques use random amplified polymorphic DNA (RAPD), repetitive elements of bacterial DNA (rep-PCR) or combined PCR followed by enzymatic digestion (RFLP). These techniques create fragments with different lengths, giving rise to a specific band profile for each strain (finger printing).

In recent years, many studies have used this molecular approach to distinguish different biotypes within the same species in the field of fermented vegetables (De Bellis et al., 2010; Franzetti et al., 2011; Aponte et al., 2012; Breidt et al., 2013a; Benítez-Cabello et al., 2019). These molecular tools are very popular to characterize and carry out phylogenetic studies on microbial communities (Abriouel et al., 2012; Lucena-Padrós et al., 2014; Romero-Gil et al., 2016).

Due to the disadvantages of these culturedependent techniques, the term "independent culture techniques" was defined, without the need for the culture of microorganisms in which DNA or RNA are extracted directly and analyzed from the food matrix. Undoubtedly, the independent culture methods offer several advantages over the dependent culture methods, such as: i) to avoid the use of specific culture media; ii) they are based on the presence of DNA, RNA, or proteins; iii) the physiological state of the cell has no affect; and iv) these methods are able to detect populations whose concentration is lower than the detection limits of traditional methods (Cocolin and Ercolini, 2007). However, the selection of the target for these techniques must satisfy two premises: i) to be common for all members of the microbial group to consider; and ii) the presence of conserved regions for the universal primer design, and variable regions for a possible differentiation. Clear examples are the genes encoding ribosomal RNA (rRNA), such as various regions of the $16 \mathrm{~S}$ genes for bacteria, or $26 \mathrm{~S}$ and ITS genes for yeasts.

At the end of the 90s, the DGGE technique (gel electrophoresis with denaturation gradient) was introduced in food microbiology (Ampe et al., 1999). Amplification of the variable 16S region combined with DGGE allowed for the discrimination of the PCR products based on their mobility as determined by the specific DNA sequence of the amplicon. DGGE has made it possible to better understand the microbial diversity of a wide variety of foods, including kimchi (Lee et al., 2005) and table olives (Abriouel et al., 2011; Benítez-Cabello et al., 2016; Lucena-Padrós et al., 2015).

Finally, from the 2010s, the use of next-generation sequencing (NGS) and metagenomics in foods, including fermented vegetables, has become widespread. These novel techniques have revolutionized the field of microbial ecology in food through more precise identification of microbial taxa without the need for culture-dependent methods. In the particular case of fermented vegetables, metagenomics has become an ideal tool for the study of the bacterial biodiversity of table olives (Cocolin et al., 2013; De Angelis et al., 2015; Medina et al., 2016b; 2018; De Castro et al., 2018), cucumbers (Medina et al., 2016a), kimchi (Hong et al., 2015, Kyung et al., 2015) and other fermented vegetables (Reina et al., 2015). However, these studies based on massive sequencing can generate partial representations of microbial diversity, so Ferrocino and Cocoli (2017) proposed using a multi-omic approach in the future, for example, combining it with metatranscriptomic or metaproteomics data.

\section{APPLICATION OF LAB AS STARTER CULTURES IN FERMENTED VEGETABLES}

The fermentation processes will be defined by different physiochemical parameters (salinity, acidity, temperature, presence of antimicrobial compounds, etc.) which will be decisive for obtaining a fermented product of high quality, which is safe and microbiologically stable. Fermentation can occur spontaneously; however, several authors recommend the use of starter cultures in order to manage the process (Corsetti et al., 2012; Lee et al., 2015). For many years, the search for starters with application in vegetables has been practically strictly focused on the activity of LAB and their technological applications. Recently, several authors have emphasized the role of selected yeasts in combination with $\mathrm{LAB}$ during processing due to their multifunctional features (Arroyo-López et al., 2012a). Yeasts could be especially effective in diverse fermented vegetables where LAB are partially inhibited by the presence of high concentrations of antimicrobial compounds, such as directly brined table olives (Arroyo-López et al., 2012a; Ruiz-Barba et al., 1993).

The selection criteria for LAB for their use as starter cultures has traditionally been related to the homo-fermentative metabolism that implies a rapid rate of sugar consumption and lactic acid production, good adaptation to intrinsic conditions of temperature, $\mathrm{pH}$, salt, and inhibitory compounds throughout the process, and resistance to bacteriophages, bacteriocin production as an important factor in establishing strains which help to increase the quality and safety, improvement in organoleptic characteristics, minimum nutritional requirement, enzymatic activities (esterase and $\beta$-glucosidase) related to the biological de-bittering of fruits, and good imposition rates, among many other characteristics (Benítez-Cabello et al., 2019; Hurtado et al., 2012). Technologically, a starter culture must have the ability to prevail against the autochthonous microbiota and resist freezing or freeze-drying processes for producing a commercial starter. Many of these starter cultures currently used in fermented 
vegetables belong to the Lactobacillus, Leuconostoc, and Pediococcus genera. Furthermore, these starter cultures should be also monitored to avoid possible negative characteristics, such as production of biogenic amines, off flavor and odor, pectinolytic activity, etc. The presence of biogenic amines has been reported in sauerkraut and table olives, where the presence of amino-biogenic spoilage microorganisms can result in high putrescine, cadaverine and tyramine contents (Medina-Pradas and ArroyoLópez, 2015; Rabie et al., 2011).

Probiotic foods have been associated for a long time with dairy products with the disadvantage of not being able to be consumed by people intolerant to lactose, in addition to their high cholesterol content (Granato et al., 2010). This scene opens a new possibility for the development of starter cultures in fermented vegetables with probiotic potential. Many researchers have studied the probiotic characteristics of several LAB species from the fermentation of sauerkraut, kimchi, cabbage, carrot or fresh beans (Argyri et al., 2013; Botta et al., 2014; BenítezCabello et al., 2019; Peres et al., 2012; Di Cagno et al., 2013;). Studies with LAB probiotic strains isolated from artichokes and table olives showed similar, even higher survival rates than those from milk probiotics during simulated human digestion (Bautista-Gallego et al., 2013; Lavermicocca et al., 2005; Arroyo-López et al., 2014).

Therefore, new challenges for the development of starter cultures should be focused on the study of the probiotic characteristics of autochthonous microorganisms present in vegetables, highlighting LAB and yeast, with the aim of establishing multifunctional mixed starter cultures that are complementary both in their properties and modes of action. Besides an appropriate technological behavior, a multifunctional starter culture must be able to exert other biological activities of interest such as cholesterol removal, inhibitory or exclusion activity against pathogenic microorganisms, resistance to acidic conditions of gastric and pancreatic digestion, phytase, antioxidant, and lactase activities, no antibiotic resistance, production of functional exopolysaccharides, adhesion to human cellular lines, and immunomodulatory activity, among others.

\section{LAB-FORMING BIOFILMS IN FERMENTED VEGETABLES}

In recent years, diverse fermented vegetables have been proven as carriers of potential probiotic microorganisms to the human body. Several studies with scanning electron microscopy have observed that some microorganisms present in the fermentation of vegetables have the ability to form biofilms on the surface of the food, as occurs with table olives (Arroyo-López et al., 2012a; DomínguezManzano et al., 2012). This biofilm is composed of a poly-microbial community, mostly of lactobacilli and yeasts, which has been embedded by an extracellular exopolysaccharide matrix whose function is to protect them from the environment and bind them to the epidermis of the fruit thanks to its adhesive properties. The EPS produced by these biofilm-forming microorganisms also has functional properties, such as to avoid adhesion of other pathogen microorganisms to animal cellular lines (González Ortiz et al., 2013). Biofilms can be formed on biotic (vegetables) or abiotic (wall fermentation vessels, machinery, etc.) surfaces.

The study of the interactions between yeasts and LAB to form biofilms, the development of mixed starter cultures and the formation of biofilms is quite recent in the field of fermented vegetables. It opens the possibility of converting these foods into an excellent vector of beneficial microorganisms to the final consumer. In several studies conducted on table olive biofilms, mixed microbial populations have been found of up to $8 \log _{10} \mathrm{CFU} \mathrm{g} \mathrm{g}^{-1}$ of L. pentosus among LAB, and Pichia galeiformis, Candida sorbosa, Geotrichum candidum, S. cerevisiae and $W$. anomalus among yeasts (Arroyo-López et al., 2012a; Domínguez-Manzano et al., 2012). Moreover, these microorganisms did not lose viability during long-term storage in olive packing at room temperature without a cold chain (RodríguezGómez et al., 2014). Certain combinations of yeasts and lactic acid bacteria favor the formation of biofilms. León-Romero et al., (2016) reported that the interaction between diverse genotypes of $C$. boidinii and $W$. anomalus in a mixed culture with $L$. pentosus formed the best biofilm, which was not found for other strains. Biofilm formation can be inhibited by the presence of $\mathrm{D}-(+)$ mannose and stimulated even in the absence of cell-cell contact between yeast and LAB species.

However, the research on the genes involved in a biofilm formation process, the modulation of their expression in a mixed culture, the interaction between yeast-LAB and with the surrounding matrix is still scarce, despite the importance of yeast-LAB cultures and the presence of biofilms in the elaboration of fermented vegetables.

\section{CONCLUSIONS}

In the last decade, research on fermented vegetables has been building on new and advanced techniques that have allowed for establishing a more solid base of knowledge about the microbial ecology implied in elaboration processes. In particular, the molecular and metagenomic techniques and the further bio-informatic analysis will allow for an in-depth study of the role of LAB throughout fermentation, the microbial changes during processing conditions, geographical and varietal influences, and application of cleaning procedures, etc. 
Moreover, the use of a new generation of multifunctional starter cultures (technological + probiotic) will result in better process control, reducing economic losses and spoilage, improving the quality and safety aspects, but at the same time, producing a product with higher functional value open new market niches.

\section{ACKNOWLEDGMENTS}

AB-C and JB-G thank the Spanish Ministry of Economy and Competitiveness for their FPI grant and JDC-Incorp. contracts, respectively.

\section{REFERENCES}

Abriouel H, Benomar N, Cobo A, Caballero N, FernándezFuentes MÁ, Pérez-Pulido R, Gálvez A. 2012. Characterization of lactic acid bacteria from naturally-fermented Manzanilla Aloreña green table olives. Food Microbiol. 32, 308-316. https://doi.org/10.1016/j. fm.2012.07.006

Abriouel H, Benomar N, Lucas R, Gálvez A. 2011. Cultureindependent study of the diversity of microbial populations in brines during fermentation of naturally-fermented Aloreña green table olives. Int. J. Food Microbiol. 144, 487-496. https://doi.org/10.1016/j.ijfoodmicro.2010.11.006

Ampe F, ben Omar N, Moizan C, Wacher C, Guyot JP. 1999. Polyphasic study of the spatial distribution of microorganisms in Mexican pozol, a fermented maize dough, demonstrates the need for cultivation-independent methods to investigate traditional fermentations. Appl. Environ. Microbiol. 65, 5464-5473

Andersson RE, Daeschel MA, Eriksson CE. 1988. Controlled lactic acid fermentation of vegetables. In Proceedings: 8 th International Biotechnology Symposium, Paris 1988/edited by G. Durand, L. Bobichon, J. Florent. [Paris, France]: Societe francaise de microbiologie, c1988

Aponte M, Blaiotta G, Croce FL, Mazzaglia A, Farina, V, Settanni L, Moschetti G. 2012. Use of selected autochthonous lactic acid bacteria for Spanish-style table olive fermentation. Food Microbiol. 30, 8-16. https://doi. org/10.1016/j.fm.2011.10.005

Argyri AA, Zoumpopoulou G, Karatzas KA, Tsakalidou E, Nychas GJ, Panagou EZ, Tassou CC. 2013. Selection of potential probiotic lactic acid bacteria from fermented olives by in vitro tests. Food Microbiol. 33, 282-291. https:// doi.org/10.1016/j.fm.2012.10.005

Arroyo-López FN, Querol A, Bautista-Gallego J, GarridoFernández A. 2008. Role of yeasts in table olive production. Int. J. Food Microbiol. 128, 189-196. https://doi. org/10.1016/j.ijfoodmicro.2008.08.018

Arroyo-López FN, Bautista-Gallego J, Domínguez-Manzano J, Romero-Gil V, Rodríguez-Gómez F, García-García P, Garrido-Fernández A, Jiménez-Díaz R. 2012a. Formation of lactic acid bacteria-yeasts communities on the olive surface during Spanish-style Manzanilla fermentations. Food Microbiol. 32, 295-301. https://doi.org/10.1016/j. fm.2012.07.003

Arroyo-López FN, Romero-Gil V, Bautista-Gallego J, Rodríguez-Gómez F, Jiménez-Díaz R, García-García P, Querol A, Garrido-Fernández A. 2012b. Yeasts in table olive processing: desirable or spoilage microorganisms? Int. J. Food Microbiol. 160, 42-49. https://doi.org/10.1016/j. ijfoodmicro.2012.08.003

Arroyo-López FN, Blanquet-Diot S, Denis S, Thévenot J, Chalancon S, Alric, M, Rodríguez-Gómez F, Romero-Gil V, Jiménez Díaz R, Garrido-Fernández A. 2014. Survival of pathogenic and lactobacilli species of fermented olives during simulated human digestion. Front. Microbiol. 5, 540. https://doi.org/10.3389/fmicb.2014.00540
Babuchowsk A, Laniewska-Moroz L, Warminska-Radyko I. 1999. Propionibacteria in fermented vegetables. Lait 79, 113-124. https://doi.org/10.1051/lait:199919

Bautista-Gallego J, Arroyo-López FN, Rantsiou K, JiménezDíaz R, Garrido-Fernández A, Cocolin LS. 2013. Screening of lactic acid bacteria isolated from fermented table olives with probiotic potential. Food Res. Int. 50, 135-142. https://doi.org/10.1016/j.foodres.2012.10.004

Bellis P de, Valerio F, Sisto A, Lonigro SL, Lavermicocca P. 2010. Probiotic table olives: microbial populations adhering on olive surface in fermentation sets inoculated with the probiotic strain Lactobacillus paracasei IMPC2.1 in an industrial plant. Int. J. Food Microbiol. 140, 6-13. https:// doi.org/10.1016/j.ijfoodmicro.2010.02.024

Benítez-Cabello A, Bautista-Gallego J, Garrido-Fernández A, Rantsiou K, Cocolin L, Jiménez-Díaz R, Arroyo-López FN. 2016. RT-PCR-DGGE Analysis to Elucidate the Dominant Bacterial Species of Industrial Spanish-Style Green Table Olive Fermentations. Front Microbiol. 7, 1291. https://doi.org/10.3389/fmicb.2016.01291

Benítez-Cabello A, Calero-Delgado B, Rodríguez-Gómez F, Garrido-Fernández A, Jiménez-Díaz R, Arroyo-López FN. 2019. Biodiversity and multifunctional features of lactic acid bacteria isolated from table olive biofilms. Front. Microbiol. 10 (3), Art 836. https://doi.org/10.3389/ fmicb.2019.00836

Botta C, Cocolin L. 2012. Microbial dynamics and biodiversity in table olive fermentation: culture-dependent and -independent approaches. Front Microbiol. 3, 245. https:// doi.org/10.3389/fmicb.2012.00245

Botta C, Langerholc T, Cencič A, Cocolin L. 2014. In vitro selection and characterization of new probiotic candidates from table olive microbiota. Plos One. 9 (4). https://doi. org/10.1371/journal.pone.0094457

Breidt F, Medina E, Wafa D, Pérez-Díaz I, Franco W, Huang, HY, Johanningsmeier SD, Kim JH. 2013a. Characterization of cucumber fermentation spoilage bacteria by enrichment culture and 16S rDNA cloning. J. Food Sci. 78, M470-476. https://doi.org/10.1111/1750-3841.12057

Breidt F, McFeeters RF, Perez-Diaz I, Lee C. 2013b. Fermented vegetables. Ch. 33 in Doyle and Buchanan, Food Microbiology: Fundamentals and Frontiers, ASM Press. https://doi.org/10.1128/9781555818463.ch33

Cagno R di, Coda R, De Angelis M, Gobbetti M. 2013. Exploitation of vegetables and fruits through lactic acid fermentation. Food Microbiol. 33, 1-10. https://doi. org/10.1016/j.fm.2012.09.003

Castro A de, Rejano L, Sánchez AH, Montaño A. 1995. Fermentation of lye-treated carrots by Lactobacillus plantarum. J. Food Sci. 60, 316-319. https://doi. org/10.1111/j.1365-2621.1995.tb05663.x

Castro A de, Sánchez AH, López-López A, Cortés-Delgado A, Medina E, Montaño A. 2018. Microbiota and Metabolite Profiling of Spoiled Spanish-Style Green Table Olives. Metabolites 8, 73. https://doi.org/10.3390/metabo8040073

Cocolin L, Ercolini D. 2007. Molecular techniques in the microbial ecology of fermented foods, Springer Science \& Business Media.

Corsetti A, Perpetuini G, Schirone M, Tofalo R, Suzzi G. 2012. Application of starter cultures to table olive fermentation: an overview on the experimental studies. Front Microbiol. 3. https://doi.org/10.3389/fmicb.2012.00248

Costilow RN, Gates K, Lacy ML. 1980. Molds in brined cucumbers: cause of softening during air-purging of fermentations. Appl. Environ. Microbiol. 40, 417-422.

Domínguez-Manzano J, Olmo-Ruiz C, Bautista-Gallego J, Arroyo-López FN, Garrido-Fernández, A, JiménezDíaz R. 2012. Biofilm formation on abiotic and biotic surfaces during Spanish style green table olive fermentation. Int. J. Food Microbiol. 157, 230-238. https://doi. org/10.1016/j.ijfoodmicro.2012.05.011

Elmacı SB, Tokatlı M, Dursun D, Özçelik F, Şanlıbaba P. 2015. Phenotypic and genotypic identification of lactic acid bacteria isolated from traditional pickles of the Cubuk region in Turkey. Folia Microbiol. 60, 241-251. https://doi. org/10.1007/s12223-014-0363-x 
Etchells JL, Bell TA. 1950. Classification of yeasts from the fermentation of commercially brined cucumbers. Farlowia 4, $87-112$.

Etchells JL, Jones ID. 1943. Bacteriological changes in cucumber fermentation. Food Industries 15, 54-56.

Ferrocino I, Cocolin L. 2017. Current perspectives in food-based studies exploiting multi-omics approaches. Curr. Opin. Food Sci. 13, 10-15. https://doi.org/10.1016/j.cofs.2017.01.002

Fleming HP, Etchells JL, Thompson RL, Bell TA. 1975. Purging of $\mathrm{Co} 2$ from Cucumber Brines to Reduce Bloater Damage. J. Food.Sci. 40, 1304-1310. https://doi. org/10.1111/j.1365-2621.1975.tb01078.x

Franco W, Pérez-Díaz IM. 2013. Microbial interactions associated with secondary cucumber fermentation. J. Appl. Microbiol. 114, 161-172. https://doi.org/10.1111/jam.12022

Franco W, Pérez-Díaz IM, Johanningsmeier SD, McFeeters RF. 2012. Characteristics of Spoilage-Associated Secondary Cucumber Fermentation. Appl. Environ Microbiol. 78, 1273-1284. https://doi.org/10.1128/AEM.06605-11

Franzetti L, Scarpellini M, Vecchio A, Planeta D. 2011. Microbiological and safety evaluation of green table olives marketed in Italy. Ann. Microbiol. 61, 843-851. https://doi. org/10.1007/s13213-011-0205-x

Garrido-Fernández A, Adams MR, Fernández-Díez MJ. 1997. Table olives: production and processing, Springer Science \& Business Media.

Gebbers JO. 2007. Atherosclerosis, cholesterol, nutrition, and statins-a critical review. GMS Ger. Med. Sci. 5, 4.

Gililland JR, Vaughn RH. 1943. Characteristics of butyric acid bacteria from olives. J. Bacteriol. 46, 315 .

González-Cancho F, Rejano-Navarro L, Rodríguez de la Borbolla, Alcalá JM. 1980. Formation of propionic acid during the conservation of table green olives, 3 : Responsible microorganisms. Grasas Aceites 31, 245-250

González-Ortiz G, Pérez JF, Gustavo-Hermes R, Molist F, Jiménez-Díaz R, Martín-Orue S. 2013. Screening the ability of natural feed ingredients to interfere with the adherence of enterotoxigenic Escherichia coli (ETEC) K88 to the porcine intestinal mucus. British J. Nutr. 111, 633-642. https://doi.org/10.1017/S0007114513003024

Granato D, Branco GF, Nazzaro F, Cruz AG, Faria JA. 2010. Functional foods and nondairy probiotic food development: trends, concepts, and products. Compr. Rev. Food Sci. Food Saf. 9 (3), 292-302. https://doi. org/10.1111/j.1541-4337.2010.00110.x

Hernández A, Martín A, Aranda E, Pérez-Nevado F, Córdoba MG. 2007. Identification and characterization of yeast isolated from the elaboration of seasoned green table olives. Food Microbiol. 24, 346-351. https://doi.org/10.1016/j. fm.2006.07.022

Hong Y, Li J, Qin P, Lee SY, Kim HY. 2015. Predominant lactic acid bacteria in mukeunji, a long-term-aged kimchi, for different aging periods. Food Sci. Biotechnol. 24, 545-550. https://doi.org/10.1007/s10068-015-0071-6

Hurtado A, Reguant C, Bordons A, Rozès N. 2012. Lactic acid bacteria from fermented table olives. Food Microbiol. 31, 1-8. https://doi.org/10.1016/j.fm.2012.01.006

Jang S, Lee J, Jung U, Choi HS, Suh HJ. 2014. Identification of an anti-listerial domain from Pediococcus pentosaceus T1 derived from Kimchi, a traditional fermented vegetable. Food Control 43, 42-48. https://doi.org/10.1016/j. foodcont.2014.02.040

Ji K, Jang NY, Kim YT. 2015. Isolation of Lactic Acid Bacteria Showing Antioxidative and Probiotic Activities from Kimchi and Infant Feces. J. Microbiol. Biotechnol. 25, 1568-1577. https://doi.org/10.4014/jmb.1501.01077

Johanningsmeier S, McFeeters RF, Fleming HP, Thompson RL. 2007. Effects of Leuconostoc mesenteroides starter culture on fermentation of cabbage with reduced salt concentrations. J. Food Sci. 72, M166-172. https://doi. org/10.1111/j.1750-3841.2007.00372.x

Johanningsmeier SD, McFeeters RF. 2013. Metabolism of lactic acid in fermented cucumbers by Lactobacillus buchneri and related species, potential spoilage organisms in reduced salt fermentations. Food Microbiol. 35, 129-135. https://doi. org/10.1016/j.fm.2013.03.004
Jung JY, Lee SH, Jin HM, Hahn Y, Madsen EL, Jeon CO. 2013. Metatranscriptomic analysis of lactic acid bacterial gene expression during kimchi fermentation. Int. J. Food Microbiol. 163, 171-179. https://doi.org/10.1016/j. ijfoodmicro.2013.02.022

Kawatomari T, Vaughn RH. 1956. Species of Clostridium associated with zapatera spoilages. J. Food Sci. 21, 481-490. https://doi.org/10.1111/j.1365-2621.1956.tb16946.x

Kim E, Cho Y, Lee Y, Han SK, Kim CG, Choo DW, Kim YR, Kim HY. 2017. A proteomic approach for rapid identification of Weissella species isolated from Korean fermented foods on MALDI-TOF MS supplemented with an inhouse database. Int. J. Food Microbiol. 243, 9-15. https:// doi.org/10.1016/j.ijfoodmicro.2016.11.027

Kyung KH, Medina E, Kim SG, Lee YJ, Kim KH, Choi JJ, Cho JH, Chung CH, Barrangou R, Breidt F. 2015. Microbial Ecology of Watery Kimchi. Food Control 80, M1031-8. https://doi.org/10.1111/1750-3841.12848

Lavermicocca P, Valerio F, Lonigro SL, Angelis MD, Morelli L, Callegari ML, Rizzello CG, Visconti A. 2005. Study of Adhesion and Survival of Lactobacilli and Bifidobacteria on Table Olives with the Aim of Formulating a New Probiotic Food. Appl. Environ. Microbiol. 71, 4233-4240. https://doi.org/10.1128/AEM.71.8.4233-4240.2005

Lee JS, Heo GY, Lee JW, Oh YJ, Park JA Park YH, Pyun YR, Ahn JS. 2005. Analysis of kimchi microflora using denaturing gradient gel electrophoresis. Int. J. Food Microbiol. 102, 143-150. https://doi.org/10.1016/j.ijfoodmicro.2004.12.010

Lee ME, Jang JY, Lee JH, Park HW, Choi HJ, Kim TW. 2015. Starter cultures for kimchi fermentation. J. Microbiol. Biotechnol. 25, 559-568. https://doi.org/10.4014/jmb. 1501.01019

León-Romero Á Domínguez-Manzano J, Garrido-Fernández A, Arroyo-López FN, Jiménez-Díaz R. 2016. Formation of in vitro mixed-species biofilms by Lactobacillus pentosus and yeasts isolated from Spanish-style green table olive Fermentations. Appl. Environ. Microbiol. 82, 689-695. https://doi.org/10.1128/AEM.02727-15

Lucena-Padrós H, Caballero-Guerrero B, Maldonado-Barragán A, Ruiz Barba JL. 2014. Microbial diversity and dynamics of Spanish-style green table-olive fermentations in large manufacturing companies through culture-dependent Techniques. Food Microbiol. 42, 154-165. https://doi. org/10.1016/j.fm.2014.03.020

Lucena-Padrós H, Jiménez E, Maldonado-Barragán M, Rodriguez JM, Ruiz-Barba JL. 2015. PCR-DGGE assessment of the bacterial diversity in Spanish-style green table olive fermentations. Int. J. Food Microbiol. 205, 47-53. https://doi.org/10.1016/j.ijfoodmicro.2015.03.033

Luke FK. 1996. Lactic acid bacteria involved in food fermentations and their present and future uses in food industry. Lactic Acid Bacteria: Current Advances in Metabolism, Genetics and Applications. Vol. H98. Ed. Faruk Bozoglu and Bibek Ray. Springer-Verlag Berlin Heidelberg.

Mattos FR, Fasina OO, Reina LD, Fleming HP, Breidt F, Damasceno GS, Passos FV. 2005. Heat Transfer and Microbial Kinetics Modeling to Determine the Location of Microorganisms within Cucumber Fruit. J. Food Sci. 70, E324-E330. https://doi.org/10.1111/j.1365-2621.2005. tb09972.x

Medina E, Arroyo-López FN. 2015. Presence of toxic microbial metabolites in table olives. Front. Microbiol. 6. https://doi. org/10.3389/fmicb.2015.00873

Medina E, Pérez Díaz IM, Breidt F, Hayes J, Franco W, Butz N, Azcarate Peril MA. 2016. Bacterial Ecology of Fermented Cucumber Rising $\mathrm{pH}$ Spoilage as Determined by Nonculture-Based Methods. J. Food Sci. 81, M121-M129. https://doi.org/10.1111/1750-3841.13158

Medina E, Ruiz-Bellido MA, Romero-Gil V, Rodríguez-Gómez F, Montes-Borrego M, Landa BB, Arroyo-López FN. 2016. Assessment of the bacterial community in directly brined Aloreña de Málaga table olive fermentations by metagenetic analysis. Int. J. Food Microbiol. 236, 47-55. https://doi.org/10.1016/j.ijfoodmicro.2016.07.014

Medina E, Brenes M, García P, Romero C. 2018. Microbial ecology along the processing of Spanish olives darkened by 
oxidation. Food Control 86, 35-41.https://doi.org/10.1016/j. foodcont.2017.10.035

Montet D, Ray RC, Zakhia-Rozis N. 2014. Lactic Acid Fermentation of Vegetables and Fruits. Microorganisms and Fermentation of Traditional Foods Chapter 4, 108140. https://doi.org/10.13140/2.1.2374.1127

Moon SH, Chang M, Kim HY, Chang HC. 2014. Pichia kudriavzevii is the major yeast involved in film-formation, offodor production, and texture-softening in over-ripened Kimchi. Food Sci. Biotechnol. 23, 489-497. https://doi. org/10.1007/s10068-014-0067-7

Pederson CS, Albury MN. 1969. The sauerkraut fermentation, bulletin 824. Geneva, NY: New York State Agricultural Experiment Station.

Peres CM, Peres C, Hernández-Mendoza A, Malcata FX. 2012. Review on fermented plant materials as carriers and sources of potentially probiotic lactic acid bacteria - With an emphasis on table olives. Trends Food Sci. Technol. 26, 31-42. https://doi.org/10.1016/j.tifs.2012.01.006

Peréz-Díaz IM, Breidt F, Buescher RW, Arroyo-López FN, Jiménez Diaz R, Garrido-Fernández, A, Bautista-Gallego J, Yoon SS, Johanningsmeire, SD. (2013). Fermented and acidified vegetables. Compendium of methods for the microbiological examination of foods, 4th edn. American Public Health Association, Washington, DC, 521-532.

Plastourgos S, Vaughn RH. 1957. Species of Propionibacterium associated with zapatera spoilage of olives. Applied Microbiology 5 (4), 267.

Plengvidhya V, Breidt F, Lu Z, Fleming HP. 2007. DNA Fingerprinting of Lactic Acid Bacteria in Sauerkraut Fermentations. Appl. Environ. Microbiol. 73, 7697-7702. https://doi.org/10.1128/AEM.01342-07

Rabie MA, Siliha H, el-Saidy S, el-Badawy AA, Malcata FX. 2011. Reduced biogenic amine contents in sauerkraut via addition of selected lactic acid bacteria. Food Chem. 129, 1778-1782. https://doi.org/10.1016/j. foodchem.2011.05.106

Randazzo CL, Restuccia C, Romano AD, Caggia C. 2004. Lactobacillus casei, dominant species in naturally fermented Sicilian green olives. Int. J. Food Microbiol. 90, 9-14. https://doi.org/10.1016/S0168-1605(03)00159-4

Rejano L, Sánchez AH, de Castro A, Montaño A. 1997. Chemical characteristics and storage stability of pickled garlic prepared using different processes. J. Food Sci. 62, 1120-1123. https://doi.org/10.1111/j.1365-2621.1997. tb12226.x

Reina LD, Pérez-Díaz IM, Breidt F, Azcarate-Peril MA, Medina E, Butz N. 2015. Characterization of the microbial diversity in yacon spontaneous fermentation at $20^{\circ} \mathrm{C}$. Int. J. Food Microbiol. 203, 35-40. https://doi.org/10.1016/j. ijfoodmicro.2015.03.007

Rodríguez-Gómez F, Arroyo-López FN, López-López A, Bautista-Gallego J, Garrido-Fernández A. 2010. Lipolytic activity of the yeast species associated with the fermentation/storage phase of ripe olive processing. Food Microbiol. 27, 604-612. https://doi.org/10.1016/j.fm.2010.02.003

Rodríguez-Gómez F, Romero-Gil V, García-García P, GarridoFernández A, Arroyo-López FN. 2014. Fortification of table olive packing with the potential probiotic bacteria Lactobacillus pentosus TOMC-LAB2. Front. Microbiol. 5. https://doi.org/10.3389/fmicb.2014.00467

Romero-Gil V, Rodríguez-Gómez F, Garrido-Fernández A, García-García P, Arroyo-López FN. 2016. Lactobacillus pentosus is the dominant species in spoilt packaged Aloreña de Málaga table olives. LWT-Food Sci. Technol. 70, 252-260. https://doi.org/10.1016/j.lwt.2016.02.058

Ruiz-Barba JL, Brenes-Balbuena M, Jiménez-Díaz R, GarcíaGarcía P, Garrido-Fernández A. 1993. Inhibition of Lactobacillus plantarum by polyphenols extracted from two different kinds of olive brine. J. Appl. Bacteriol. 74 (1), 15-19. https://doi.org/10.1111/j.1365-2672.1993.tb02990.x

Samish Z, Etinger-Tulczynska R, Bick M. 1963. The Microflora Within the Tissue of Fruits and Vegetables. J. Food Sci. 28, 259-266. https://doi.org/10.1111/j.1365-2621.1963. tb00194.x

Sánchez AH, de Castro A, Rejano L. 1992. Controlled fermentation of caperberries. J. Food Sci. 57, 675-678. https://doi. org/10.1111/j.1365-2621.1992.tb08069.x

Tamminen M, Joutsjoki T, Sjöblom M, Joutsen M, Palva A, Ryhänen EL, Joutsjoki V. 2004. Screening of lactic acid bacteria from fermented vegetables by carbohydrate profiling and PCR-ELISA. Lett. Appl. Microbiol. 39, 439-444. https://doi.org/10.1111/j.1472-765X.2004.01607.x

Tofalo R, Perpetuini G, Schirone M, Ciarrocchi A, Fasoli G, Suzzi G, Corsetti A. 2014. Lactobacillus pentosus dominates spontaneous fermentation of Italian table olives. LWT - Food Sci. Technol. 57, 710-717. https://doi. org/10.1016/j.1wt.2014.01.035

Vaughn RH, Stevenson KE, Davé BA, Park HC. 1972. Fermenting yeasts associated with softening and gas-pocket formation in olives. Appl. Microbiol. 23 (2), 316-320.

Yan P, Chai Z, Chang X, Zhao W, Yue H, Zhang T. 2015. Screening and identification of microorganism degrading nitrite in Chinese sauerkraut. Agro Food Ind. HiTech. 26, $20-23$.

Yu J, Gao W, Qing M, Sun Z, Wang W, Liu W, Pan L, Sun T, Wang H, Bai N, Zhang H. 2012. Identification and characterization of lactic acid bacteria isolated from traditional pickles in Sichuan, China. J. Gen. Appl. Microbiol. 58 (3), 163-172.

Yue, XQ, Li X, Wu JR, Zhang M. 2013. Isolation and Identification of Lactobacillus from Naturally Fermented Sauerkraut Juices in Xifeng. Adv. Mater. Res Res. 726731, 147-150. https://doi.org/10.4028/www.scientific.net/ AMR.726-731.147 